Szilágyi-Gál, Mihály. "Kelemen, János. 2013. The Rationalism of Georg Lukács.” Hungarian Cultural Studies. e-Journal of the American Hungarian Educators Association, Volume 7 (2014): http://ahea.pitt.edu DOI: $10.5195 /$ ahea.2014.160

\title{
Kelemen, János. 2013. The Rationalism of Georg Lukács. Basingstoke: Macmillan, Palgrave Pivot. 144 pp.
}

\section{Reviewed by Mihály Szilágyi-Gál, Eötvös Loránd University, Budapest}

The name of the most famous Hungarian philosopher of all time, Georg/György Lukács (1886-1971), has been almost entirely ignored in Hungary, at least since the collapse of the state-socialist regime in 1989. With the exception of marginal conference panels, short papers and memories of his contemporaries and disciples presented mainly at private seminars, with a restricted and often foreign audience, the philosophy of Lukács does not appear in the curricula of Hungarian academic life. This is so despite the fact that during his lifetime almost all his works, most of which were originally written in German, have been translated into Hungarian (presently most if not all his major works are available in English as PDF documents on the Internet, which attests to the interest in his work). In Hungary of the last three decades none of Lukács's books has been reprinted, and no distinct new volumes have appeared about his work. The name of György Lukács has in fact become a taboo in present-day Hungary.

Beyond doubt, both Lukács's pathbreaking works in philosophy, history of literature and art criticism, and his political involvement in the short-lived Hungarian Soviet Communist Republic of March-August 1919 ignited many controversies regarding his life and work. After his early pre-Marxist writing about art theory, especially Soul and Form (trans. Anna Bostock, ed. John Sanders and Katie Terzakis; New York: Columbia University Press, 2010 [1911]) and The Theory of the Novel - a Historico-Philosophical Essay on the Form of Great Epic Literature (trans. Anna Bostock; London: Merlin press, 1971 [1920]), which was inspired by Kantian and Hegelian notions, Lukács joined the Hungarian Communist Party and became active in the cultural and educational policy of the 1919 Hungarian Soviet Communist Republic, during which, as the People's Commissar, he was indirectly involved in the execution of eight dissidents. In the following two decades Lukács lived in Austria, Germany, Italy, and the Soviet Union. His connections with artists and theoreticians, including Thomas Mann who is known to have conceived the protagonist Nahpta in his novel Magic Mountain about Lukács, are also revoked in Kelemen's book. Lukács rejected the suprarealist style of various avant garde currents and pleaded for the realist modernism he put forward in The Theory of the Novel and in other works. Kelemen quotes Ferenc Fehér (1933-1994), a former disciple of Lukács, claiming that in Lukács's literary theory realism is supposed to be understood in terms of his rationalism. Kelemen infers that this stance expresses Lukács's aesthetic antimodernism, meaning that he was at odds with leading modernist currents of the time, especially with Expressionism. In the late 1940s Lukács took part in shaping the cultural policy of the emerging state-socialist regime. During the purges that followed the 1956 events, he barely escaped execution for his role in the preceding revolutionary government of Imre Nagy. He was supervised, interrogated and marginalized for an entire decade, as a

$(\mathrm{cc}) \mathrm{BY}$

ULLS D-Serle
New articles in this journal are licensed under a Creative Commons Attribution 4.0 International License.

This journal is published by the University Library System of the University of Pittsburgh as part of its D-Scribe Digital Publishing Program and is cosponsored by the University of Pittsburgh Press 
Szilágyi-Gál, Mihály. "Kelemen, János. 2013. The Rationalism of Georg Lukács.” Hungarian Cultural Studies. e-Journal of the American Hungarian Educators Association, Volume 7 (2014): http://ahea.pitt.edu DOI: $10.5195 /$ ahea.2014.160

result of which he could only publish abroad. After he expressed self-criticism of his political actions and involvement, he was admitted to the Communist Party and continued to express hope for a less bureaucratic and more humanistic phase in the socialist system.

The silence in the very country of birth of one of the most influential Marxist thinkers of our time, regardless of how complex his political background was, is a provoking phenomenon and in itself deserves the attention of historians of philosophy. But this is not the topic of János Kelemen's present volume, in which he addresses a fundamental aspect of Lukács's philosophy, namely his theory of rationalism. To carry out this endeavor, Kelemen examines Lukács's work from a rigorous conceptual perspective; thus he keeps the political aspects of Lukács's studies of rationalism in the background while focusing solely on his philosophical arguments.

Kelemen's contentions are the following: 1. Lukács does not acknowledge that his deterministic approach implies that choosing rationalism is irrational. 2. Lukács ignores both bourgeois gestures, like the attempt of the 1920s Vienna Circle (of philosophers hailing logical positivism) to fight against irrationalism, and the irrational tendencies of totalitarian politics. 3. Contrary to Lukács, we are not necessarily pre-determined in our choice for rationalism but have a rational reason for making choices, which means that rationalism is the result of both evolution and history. Here Kelemen suggests that given that rationalism appears as a stronger natural and human heritage than irrationalism, we have rational reasons to choose it. 4. Lukács's conception of science is interesting for its relevance to the author's overall conception of society and politics rather than for its value in the philosophy of science. 5. Kelemen's central thesis is that there is a wholesome and systematic conception of rationalism in Lukács's comprehensive work, including even his early pre-Marxist phase. Furthermore, his particular view of rationalism is not only a recurring stance in all of his work but also a programmatic part of his methodology. Thus rationalism for Lukács is a matter or a principle of both content and form. 6. Lukács' philosophy of language consists of his contention that language reflects labor and social class relations.

The philosophy of Lukács can hardly be explained separately from his activity as a literary historian and as an art critique. Therefore Kelemen's exploration considers and encompasses Lukács's inclusive work, with special focus on his three central works: History and Class Consciousness - Studies in Marxist Dialectics (trans. Rodney Livingstone; London: Merlin Press, 1971 [1923]), The Destruction of Reason (trans. Peter R. Palmer; London: Merlin Press, 1980 [1954]), and Die Eigenart des Aesthetischen [The Specificity of the Aesthetic] (Berlin and Weimar: Aufbau Verlag, 1963). The two parts of Kelemen's book, "To Supervise the Existence of Reason" and "Problems of Literary History and Aesthetics," together contain seven chapters. As the author states in the introduction, the volume is a collection of essays published at different times yet treating interconnected topics. Following the introduction, each chapter studies Lukács's view of rationalism with regard to phenomena and criteria such as language, science, aesthetics, history, literature and film.

Kelemen discusses Lukács's philosophy following his anti-positivistic phase and presents him as a critical forerunner of later influential philosophers of science like Thomas Kuhn (1922-1996) and Paul Feyerabend (1924-1994). Lukács's exceptionally early anti-positivism contends that there are neither pure facts nor observations that are free of the complex structures of the acts of observing and identifying them as facts, and 
Szilágyi-Gál, Mihály. "Kelemen, János. 2013. The Rationalism of Georg Lukács.” Hungarian Cultural Studies. e-Journal of the American Hungarian Educators Association, Volume 7 (2014): http://ahea.pitt.edu DOI: $10.5195 /$ ahea.2014.160

therefore scientific observations are themselves anchored in historical and social contexts. Kelemen clarifies that in this respect Lukács's views are opposed to the cross-contextual rationalism of Karl Popper (1902-1994) that defends the possibility of theory-free scientific observations. Still, Lukács and Popper agree about the political dangers of irrationalism and its visible connection to fascism. Kelemen reconstructs Lukács's claim that although science is a rational undertaking, the extension of the ground rules of natural sciences to the understanding of society is inacceptable. Accordingly, social sciences cannot emulate methods of natural sciences and instead have to create their own inquiry methods. Lukács never gave up this thesis, which had already been proposed at his time by Neo-Kantians philosophers like Heinrich Rickert (1863-1936), Lukács's teacher at Heidelberg, Germany in the 1910s, and Ernst Cassirer (1874-1945).

Whereas in History and Class Consciousness Lukacs's contention is that natural and social sciences are separate, in The Specificity of the Aesthetic he argues for the idea of a unified science, but without giving up his earlier contention that social sciences are not supposed to import methodologies of natural sciences. The idea of the "totality" of science (which in History and Class Consciousness was still restricted to social sciences alone) consists of the demand of an all-embracing view of human development. Kelemen criticizes Lukács's later conception of the so-called unified "proletarian science," which meant to view human development from the perspective of the proletariat, as inaccurate because it does not supply a clear conception of any scientific research methodology. Lukács's totalistic conception of science has been criticized by several philosophers, among them Mihály Vajda (b. 1935), one of Lukács closest disciples, who rejects the faith of his master in rationalism. Lukács contends that the philosophy of science also means a critique of science and this embraces science's social and political dimensions as well. But for a deeper understanding of Lukács's views in this respect one has to return to his conception of rationalism.

Lukács's first novel contribution regarding the concept of rationalism was the contention that bourgeois rationalism is purely instrumental and suited to the needs of capitalism and its dominant class and -- as such -- it is bound to lead to irrationalism. Kelemen reconstructs the presence of this particular idea in both History and Class Consciousness (1923) and The Destruction of Reason (1954). He reconstructs Lukács's arguments that irrationalism is always a reaction to the shortcomings of rationalism and that the choice for both is determined by social factors. In The Destruction of Reason we come across Lukács's second novel contribution: instead of the old Marxist distinction between idealism and materialism, he introduces a distinction between irrationalism and rationalism. According to Lukács, since both rationalism and irrationalism are the outcomes of social and historical factors, we never decide in favor of either rationalism or irrationalism. Although The Destruction of Reason has been widely criticized, mainly for its too harsh thesis that bourgeois irrationalism directly leads to fascism, Kelemen defends the book for its innovative approach to rationalism.

Besides providing many valuable insights about Lukács's work, especially regarding central aspects of his philosophy of language, the most important contribution of Kelemen's volume consists of his demonstration of the unity and persistence of Lukács's conception of rationalism and its fundamental social, historical, political and aesthetic dimensions. The book also reflects Kelemen's own professional merits as a philologist, researcher of Italian literary history and philosopher of language. The chapter analyzing the 
Szilágyi-Gál, Mihály. "Kelemen, János. 2013. The Rationalism of Georg Lukács.” Hungarian Cultural Studies. e-Journal of the American Hungarian Educators Association, Volume 7 (2014): http://ahea.pitt.edu

DOI: $10.5195 /$ ahea.2014.160

views of Lukács's and Lajos Fülep (1885-1970) concerning the aesthetics of Benedetto Croce (1866-1952) in Florence of the 1920s sheds a unique ray of light on Lukács's rationalism in his polemics with these two theoreticians of art. To conclude, the central merit of János Kelemen's study of Lukács's philosophy is its comprehensive and careful tracing of the systematic unity of Lukács's conception of rationalism in every period of his writing as well as in his professional and political activities. It is therefore deplorable that this remarkable study, like other studies of the internationally renowned Hungarian philosopher Georg/György Lukács, came out not in Hungary and is therefore not likely to be read by too many Hungarian readers. 